\title{
Development of the Press Extraction Method for Plug Substrate Analysis: Quantitative Relationships Between Solution Extraction Techniques
}

\author{
Holly L. Scoggins ${ }^{1}$, Douglas A. Bailey ${ }^{2}$, and Paul V. Nelson \\ Department of Horticultural Science, Box 7609, North Carolina State \\ University, Raleigh, NC 27695-7609
}

Additional index words. saturated media extract, SME, soilless media, soil testing, plug nutrition, coir

\begin{abstract}
Substrate electrical conductivity (EC), pH, and nutrient content should be monitored frequently during seedling plug production. Current testing methods are either complicated, unsuited to plug production, or interpretation standards do not exist. This study compares the press extraction (PE) method developed at North Carolina State Univ. with the saturated media extract (SME) method and the 1 substrate : 2 water suspension method (1:2). These solution extraction methods were applied to plug trays containing peat-based germination mix treated with four levels of fertilizer. Two sample sizes of 20 or 60 plug cells were used to determine if the smaller, less destructive sample size would produce satisfactory results. Resulting $\mathrm{pH}$ values varied within 0.3 units among methods, but variability in EC and nutrient content was greater. The $P E$ method resulted in the highest values for $\mathrm{EC}, \mathrm{NH}_{4}{ }^{+}-\mathrm{N}, \mathrm{NO}_{3}^{-}-\mathrm{N}, \mathrm{K}, \mathrm{Ca}$, and $\mathrm{Mg}$ while sample size had little effect on analyses. The three extraction methods were then compared on peat- and coir-based substrates. Within substrates, $\mathrm{pH}, \mathrm{EC}$, and nutrients tested were similar for the PE and the SME. The coir extract had a higher $\mathrm{pH}$ and much higher levels of $\mathrm{K}$ and $\mathrm{Na}$ than did the peat extract but was lower in $\mathrm{N}, \mathrm{P}, \mathrm{Ca}$, and $\mathrm{Mg}$. Overall, fairly strong correlations among testing methods were found, especially between the SME and PE.
\end{abstract}

Maintaining optimum fertility levels is difficult for plugs because: 1) cell volumes are small, resulting in little buffering of nutrients by substrates; and 2) the large seedling : substrate volume ratio results in either rapid uptake of nutrients or dilution/leaching effects from watering (Compton and Nelson, 1997). Substrate $\mathrm{pH}$ and soluble salts should be monitored weekly, as seedlings are especially sensitive to extreme levels of soluble salts (Fonteno et al., 1995). Substrate electrical conductivity (EC) is a reliable indicator of the soluble salts concentration (Poole and Chase, 1987). Substrate $\mathrm{pH}, \mathrm{EC}$, and nutrient concentrations can be monitored by analyzing samples in the greenhouse or sending samples to a labora-

Received for publication 18 July 2000. Accepted for publication 29 Nov. 2000. The research reported herein was funded in part by the Fred C. Gloeckner Foundation, Inc., and the North Carolina Commercial Flower Growers' Association. Mention of products does not imply endorsement of these products over similar products by North Carolina State University. The authors gratefully acknowledge the technical assistance of Ingram McCall. The cost of publishing this paper was defrayed in part by the payment of page charges. Under postal regulations, this paper therefore must be hereby marked advertisement solely to indicate this fact.

${ }^{1}$ Current address: Department of Horticulture, Virginia Tech, 301C Saunders, Blacksburg, VA 24061. E-mail: hollysco@vt.edu.

${ }^{2}$ Current address: Department of Horticulture, Univ. of Georgia, 1111 Plant Science Bldg., Athens, GA 30601 . tory. However, appropriate procedures at both the sampling and analysis stage are necessary to obtain consistent and reliable results (Lang, 1996). Current greenhouse (peat-based) substrate $\mathrm{pH}$ and soluble salts interpretation ranges are based on: 1) 1 substrate : 2 water (v/v) suspension (1:2) (Lang, 1996); 2) the saturated media extract (SME) method (Warncke, 1986); or 3) the pour-through extraction method (Wright et al., 1990). Interpretive standards for nutrient content are only available for SME.

The press extraction method (PE) is a viable alternative to conventional testing methods. A variation on this method had been introduced as the "squeeze" extraction by researchers at North Carolina State Univ. (Compton and Nelson, 1997; Fonteno et al., 1995). The PE is very simple and quick. One hour after liquid fertilizer is applied, while the substrate is still at or close to container capacity, the grower picks up a representative tray and presses several plugs, collecting the expelled solution for immediate analysis. Precedent for press-type testing does exist, as Sonneveld et al. (1974) used solution expelled by a hydraulic press as the "standard closest to the actual root zone solution" with which to compare the 1:1.5 and 1:25 suspension methods. In previous experiments (Scoggins et al., 2000), varying the force applied within a range likely to be manually applied by growers did not affect the $\mathrm{pH}, \mathrm{EC}$, or nutrient analysis of the extracted solution.
The saturated media extract (SME) is most commonly used by commercial laboratories (Warncke, 1986). Greenhouse growers can test for $\mathrm{pH}$ and $\mathrm{EC}$ on-site by the 1:2 method (Nelson, 1998). Neither method is particularly suited to plug production. Both the SME and 1:2 methods require removal of the substrate from the plug tray and the subjective addition of water (Fonteno et al., 1995). Also, as plugs reach transplant size (especially for trays with $\geq 288$ cells), roots comprise much of the volume of the cell, making removal of enough substrate to perform either method difficult. The pour-through method (Wright et al., 1990) of root-zone solution displacement is rapidly gaining acceptance for bedding and pot plant testing. However, this method is difficult for plug systems. The short substrate column limits the effectiveness of using gravity as the solution extraction force (Fonteno, 1996). In addition, vigorous shoot growth in the later stages of plug production often covers the tray, leaving little or no surface area for applying the displacing water (personal observation).

Depending on the extraction method used, alternative substrates such as coir may yield differing results. Properties of peat and coir have been compared (Evans et al., 1996; Handreck, 1993; Meerow, 1995); however, the impact of different extraction methods on the resulting solution has not.

Protocol for the SME method suggests using $400 \mathrm{~mL}$ of substrate per sample (Warncke, 1986). This would require $\approx 70$ plugs from a 288-cell tray. A smaller sample would reduce the grower's losses associated with testing.

The objectives of this study were to: 1) compare SME and 1:2 methods with PE for use in the analysis of a greenhouse substrate; 2) examine the relationships between these methods if a different substrate component (coir) were used; and 3) determine if sample size (number of plugs per analysis) affected the results.

\section{Materials and Methods}

Comparisons among extraction methods-peat-based substrate (Expt. 1)

Plug flats (288 cells, $5.7 \mathrm{~mL} / \mathrm{cell})$ were filled with commercial peat-based germination mix containing dolomitic limestone and a preplant nutrient charge (4-P; Fafard, Anderson, S.C.). The flats were placed in watertight trays on a greenhouse bench and fertilizer (20N-4.3P-16.6K; Peter's Peat-Lite Special, Scotts, Marysville, Ohio) was applied via subirrigation at four concentrations $(50,100$, 150 , and $\left.200 \mathrm{mg} \cdot \mathrm{L}^{-1} \mathrm{~N}\right)$. Flats were removed from trays after $30 \mathrm{~min}$. After $24 \mathrm{~h}$, flats were again subirrigated with the fertilizer treatments ( $1 \mathrm{~h}$ prior to testing), removed from trays, and allowed to drain.

There were five replications (plug flat $=$ experimental unit) for each fertilizer rate. Samples for the three substrate solution extraction methods (SME, 1:2, and PE) were collected from each flat. The extract was analyzed for $\mathrm{pH}$ and EC (EXTECH $695 \mathrm{pH} /$ 
Conductivity Meter, Waltham, Mass.) using the following protocol for each method. To inhibit further nitrification of $\mathrm{NH}_{4}{ }^{+}-\mathrm{N}$ present in the solution, $3.0 \mathrm{~N} \mathrm{HCl}$ was added to each sample to lower $\mathrm{pH}$ to $\approx 3.0$. The extract was tested for $\mathrm{NH}_{4}{ }^{+}-\mathrm{N}, \mathrm{NO}_{3}{ }^{-}-\mathrm{N}$ (Lachat Quik Chem 8000; Zellweger Analytics, Milwaukee, Wis.), and $\mathrm{P}, \mathrm{K}, \mathrm{Ca}$, and $\mathrm{Mg}$ (Plasma 2000; Perkin Elmer Corp., Norwalk, Conn.).

$S M E$. Samples from 20 or 60 cells were chosen randomly and placed in a beaker. Deionized water was added while gently mixing until the sample was saturated to the point of "glistening," then allowed to equilibrate for 30 min (Warncke, 1986). The sample was transferred to a Büchner funnel lined with filter paper (Whatman \#1), placed over a vacuum flask, and the solution removed under vacuum. The extract was then tested for $\mathrm{pH}$ and $\mathrm{EC}$, and sent on for nutrient analysis.

1:2. Again, substrate from 20 or 60 plug cells was randomly removed from the flat and placed in a beaker. The plugs were gently stirred (broken up) to determine volume (around $110 \mathrm{~mL}$ for 20 plugs and $330 \mathrm{~mL}$ for 60 plugs), and deionized water was added at a rate of twice the substrate volume. The sample was stirred thoroughly and allowed to equilibrate for $30 \mathrm{~min}$. The $\mathrm{pH}$ and $\mathrm{EC}$ electrodes were placed directly into the slurry. Nutrient analysis was not performed on 1:2 samples, as most commercial laboratories in the United States do not have interpretive standards for this method.

$P E$. Plug trays were held over a beaker, 20 or 60 cells were pressed to expel the solution, and $\mathrm{pH}$ and $\mathrm{EC}$ readings were taken on the unfiltered extract. Solution samples were later filtered as required for the nutrient analysis.

Data were analyzed as a split-plot. The plug tray treatments of different fertilizer rates, the main plot factor, were arranged in a randomized complete-block design (RCBD). Sample size and solution extraction methods were subplot factors. Data were subjected to analysis of variance (ANOVA) using the general linear model procedure (SAS Institute, Cary, N.C.). When analysis showed a significant main effect or interaction, Fisher's protected LSD was used to compare the means of the qualitative factors (extraction method and sample size). Means of the quantitative factor, fertilizer rate, were subjected to trend analysis.

\section{Comparisons among extraction} methods-coir- vs. peat-based substrates (Expt. 2)

Plug trays ( 288 cells, $5.7 \mathrm{~mL} / \mathrm{cell}$ ) were cut into sections of 72 cells and filled with 3 sphagnum peat : 1 perlite $(\mathrm{v} / \mathrm{v})$ or 3 coir : 1 perlite $(\mathrm{v} / \mathrm{v})$. No lime or nutrient amendments were added. Four fertilizer treatments of 0 (water), 100, 200, and $300 \mathrm{mg} \cdot \mathrm{L}^{-1} \mathrm{~N}$ from $15 \mathrm{~N}-2.15 \mathrm{P}-12.45 \mathrm{~K}-5 \mathrm{Ca}-2 \mathrm{Mg}$ (Miracle Gro Excel Cal-Mag®; Scotts) were randomly assigned within each block. Increments between fertilizer rates were increased relative to Expt. 1 , to ensure that changes in EC and nutrient content could be detected. Trays were subirrigated with appropriate fertilizer treat- ments until the substrate was saturated, drained to container capacity, and equilibrated for $1 \mathrm{~h}$ before testing. The treatments were arranged in a factorial design of 2 (substrates) $\times 4(\mathrm{~N}$ rates) in a RCBD with five replications on greenhouse benches.

The three previously described solution extraction methods were used on each plug tray with 20 plugs removed for SME and 1:2 and 20 plugs pressed for PE. The solution $\mathrm{pH}$ and EC were recorded for all three methods and the SME- and PE-extracted solution analyzed for $\mathrm{NH}_{4}{ }^{+}-\mathrm{N}, \mathrm{NO}_{3}{ }^{-}-\mathrm{N}, \mathrm{P}, \mathrm{K}, \mathrm{Ca}, \mathrm{Mg}$, and $\mathrm{Na}$ content as previously described. ANOVA for $\mathrm{pH}, \mathrm{EC}$, and nutrient concentration were performed according to the split-plot experimental design with combinations of substrate by fertilizer rate as whole-plot factors and solution extraction method as the subplot factor. When model analysis showed a significant main effect or interaction, substrate and method means were compared using Fisher's protected LSD, and rate means were subjected to trend analysis.

\section{Results and Discussion}

\section{Comparisons among extraction} methods-peat-based substrate (Expt. 1)

$p H$ and EC. Extraction method significantly affected $\mathrm{pH}$ (Tables 1 and 2). Although $\mathrm{pH}$ values obtained by the three methods differed statistically, the difference between SME and PE methods was only $0.1 \mathrm{pH}$ unit. Differences in $\mathrm{pH}$ among fertilizer rates or between sample sizes, and interactions among treatments were all insignificant (Table 1). The fertilizer used in this experiment did not contain $\mathrm{Ca}$ or a significant amount of $\mathrm{Mg}$; this, coupled with the relatively narrow range of fertilizer concentrations, may account for the lack of a rate effect on $\mathrm{pH}$.

Extraction method had a much greater effect on EC, accounting for $86 \%$ of the total treatment mean squares (MS) (Table 1). Increasing fertilizer rates increased $\mathrm{EC}$ for SME and PE but not for the 1:2 method, a probable reason for the significant rate $\times$ method interaction (Table 1). The substantial dilution inherent in the 1:2 method resulted in the highest

Table 1. Mean square from analysis of variance for comparison of $\mathrm{pH}$ and electrical conductivity (EC) among press extraction (PE), saturated media extraction (SME), and 1:2 method [1 substrate : 2 water (v/v)] (Expt. 1) (df= degrees of freedom).

\begin{tabular}{lrlc}
\hline & \multicolumn{3}{c}{ Mean Square } \\
\cline { 2 - 4 } Source & df & $\mathrm{pH}$ & $\mathrm{EC}$ \\
\hline Rep & 4 & $0.04^{* * * *}$ & $0.39^{* * * *}$ \\
Rate (R) & 3 & $0.17^{\mathrm{Ns}}$ & $1.14^{*}$ \\
Error A & 9 & 0.32 & 0.32 \\
Sample Size (SS) & 1 & $0.01^{\mathrm{Ns}}$ & $0.27^{*}$ \\
Method (M) & 2 & $0.78^{* * *}$ & $15.30^{* * * *}$ \\
$\mathrm{SS} \times \mathrm{R}$ & 3 & $0.01^{\mathrm{Ns}}$ & $0.01^{\mathrm{Ns}}$ \\
$\mathrm{R} \times \mathrm{M}$ & 6 & $0.01^{\mathrm{Ns}}$ & $0.24^{* * *}$ \\
$\mathrm{SS} \times \mathrm{M}$ & 2 & $0.01^{\mathrm{Ns}}$ & $0.03^{\mathrm{Ns}}$ \\
$\mathrm{SS} \times \mathrm{R} \times \mathrm{M}$ & 6 & $0.01^{\mathrm{Ns}}$ & $0.01^{\mathrm{Ns}}$ \\
Error B & 60 & 0.30 & 0.05 \\
Total & & 1.66 & 17.74 \\
\hline Ns, *,*** Nonsignificant or significant at $P \leq 0.05$ or \\
\multicolumn{2}{l}{0.001, respectively }
\end{tabular}
0.001 , respectively.
$\mathrm{pH}$ and lowest EC (Table 2). This agrees with Warncke's (1990) observations when comparing the SME and 1:2 methods. Differences in EC between the PE and SME methods ranged from 0.3 to $0.6 \mathrm{dS} \cdot \mathrm{m}^{-1}$. Though these were significant, the variations are within acceptable EC interpretation values (0.75-1.99 $\mathrm{dS} \cdot \mathrm{m}^{-1}$ ) for plugs tested with the SME procedure (Fonteno et al., 1995). Again, there was a greater degree of dilution with SME as EC values were consistently lower than results obtained with PE.

Nutrients. Although statistically significant, the differences between SME and PE extraction methods for $\mathrm{NH}_{4}^{+}-\mathrm{N}, \mathrm{NO}_{3}^{-}-\mathrm{N}$, and $\mathrm{K}$ are relatively small (Tables 3 and 4 ). Compared with SME, PE yielded somewhat higher levels of $\mathrm{K}$ and both $\mathrm{N}$ forms but twice the levels of $\mathrm{Ca}$ and $\mathrm{Mg}$ (Table 3). As the PE extract was not filtered until the time of nutrient analysis, further dissolution of lime particles present in the extract may have occurred. Warncke (1990), however, noted the greater difficulty of detecting available $\mathrm{Ca}$ and $\mathrm{Mg}$ than of available $\mathrm{K}$ with water extracts because of the divalent nature (thus tighter bonding) of these nutrients. Extraction method had the least impact on $\mathrm{P}$, probably because of its lower solubility and therefore relatively weak response to dilution (Sonneveld, 1990). As expected, $\mathrm{NH}_{4}{ }^{+}-\mathrm{N}, \mathrm{NO}_{3}^{-}-\mathrm{N}, \mathrm{P}$, and Kincreased with increasing fertilizer rate (Table 3 ). The only significant interaction among or between rate, sample size, or method of extraction was a negligible interaction between rate and method for $\mathrm{NH}_{4}-\mathrm{N}$ (Table 4). Sample size, though significant for $\mathrm{NH}_{4}^{+}-\mathrm{N}, \mathrm{P}$, and $\mathrm{K}$, accounted for $<1 \%$ of the total variation among treatments for these nutrients. Given the limited effect sample size has on nutrient concentration, 20 plugs are recommended for the PE method to limit destruction of plant material. Because of the significant replication effect for $\mathrm{pH}, \mathrm{EC}$, and several nutrients, taking samples from several flats is recommended to better measure existing spatial variation.

\section{Comparisons among extraction} methods-coir- vs. peat-based substrates (Expt. 2)

pH and EC. Substrate, fertilizer rate, and extraction method affected $\mathrm{pH}$ (Table 5). In-

Table 2. Effect of extraction methods on $\mathrm{pH}$ (no rate effect) and electrical conductivity (EC) (by rate) for press extraction method (PE), saturated media extraction (SME), and 1:2 method [1 substrate : 2 water (v/v)] (Expt. 1).

\begin{tabular}{lccc}
\hline & PE & SME & $1: 2$ \\
\hline $\mathrm{pH}$ & $5.7 \mathrm{c}$ & $5.8 \mathrm{~b}$ & $6.1 \mathrm{a}$
\end{tabular}

Rate $\left(\mathrm{mg} \cdot \mathrm{L}^{-1} \mathrm{~N}\right)$

50

100

150

200

Significance

\begin{tabular}{ccc}
\multicolumn{3}{c}{$\mathrm{EC}\left(\mathrm{dS} \cdot \mathrm{m}^{-1}\right)$} \\
\hline $1.7 \mathrm{a}^{\mathrm{z}}$ & $1.2 \mathrm{~b}$ & $0.4 \mathrm{c}$ \\
$1.8 \mathrm{a}$ & $1.2 \mathrm{~b}$ & $0.4 \mathrm{c}$ \\
$1.9 \mathrm{a}$ & $1.4 \mathrm{~b}$ & $0.4 \mathrm{c}$ \\
$1.9 \mathrm{a}$ & $1.6 \mathrm{~b}$ & $0.5 \mathrm{c}$ \\
$\mathrm{Q}^{* *}$ & $\mathrm{Q}^{* *}$ & NS
\end{tabular}

${ }^{2}$ Means separation within rows by LSD at $P \leq 0.05$ (n $=10)$.

Ns, ${ }^{* *}$ Nonsignificant or significant within column at $P$ $\leq 0.01 ; \mathrm{Q}=$ quadratic $(\mathrm{n}=40)$ 
Table 3. Effects of press extraction method (PE) vs. saturated media extraction (SME) and rate of $\mathrm{N}$ applied as macronutrient content of substrate (mg $\mathrm{L}^{-1}$ ) (Expt. 1).

\begin{tabular}{|c|c|c|c|c|c|c|c|c|c|c|c|c|}
\hline \multirow{2}{*}{$\begin{array}{l}\text { Rate } \\
\left(\mathrm{mg} \cdot \mathrm{L}^{-1} \mathrm{~N}\right)\end{array}$} & \multicolumn{2}{|c|}{$\mathrm{NH}_{4}-\mathrm{N}$} & \multicolumn{2}{|c|}{$\mathrm{NO}_{3}{ }^{-} \mathrm{N}$} & \multicolumn{2}{|c|}{$\mathrm{P}$} & \multicolumn{2}{|c|}{$\mathrm{K}$} & \multicolumn{2}{|c|}{$\mathrm{Ca}$} & \multicolumn{2}{|c|}{$\mathrm{Mg}$} \\
\hline & SME & $\mathrm{PE}$ & SME & $\mathrm{PE}$ & SME & PE & SME & $\mathrm{PE}$ & SME & $\mathrm{PE}$ & SME & $\mathrm{PE}$ \\
\hline 50 & 25 & $37^{*}$ & 58 & $91^{*}$ & 24 & $31^{*}$ & 118 & $75^{*}$ & 51 & $121^{*}$ & 50 & $104^{*}$ \\
\hline 100 & 30 & $36^{*}$ & 74 & $93^{*}$ & 32 & 35 & 137 & $176^{*}$ & 50 & $101^{*}$ & 50 & $91^{*}$ \\
\hline 150 & 39 & $44^{*}$ & 96 & $113^{*}$ & 37 & 40 & 167 & $198^{*}$ & 56 & $122^{*}$ & 53 & $106^{*}$ \\
\hline 200 & 44 & $51^{*}$ & 110 & $137^{*}$ & 48 & 50 & 194 & $228^{*}$ & 59 & $114^{*}$ & 56 & $100^{*}$ \\
\hline Significance & $\mathrm{L}^{* * * *}$ & $\mathrm{~L}^{* * *}$ & $\mathrm{~L}^{* * * *}$ & $\mathrm{~L}^{* * * *}$ & $\mathrm{~L}^{* * *}$ & $\mathrm{~L}^{* * *}$ & $\mathrm{~L}^{* * * *}$ & $\mathrm{~L}^{* *}$ & NS & NS & NS & NS \\
\hline
\end{tabular}

*Mean significantly different from SME at same $\mathrm{N}$ rate at $P \leq 0.05(\mathrm{n}=10)$.

Ns, ${ }^{* *}, * * *$ Nonsignificant or significant at $P \leq 0.01$ or 0.001 ; no quadratic responses observed.

Table 4. Mean squares from analysis of variance for solution macronutrient content between press extraction (PE) and saturated media extraction (SME) (Expt. 1).

\begin{tabular}{|c|c|c|c|c|c|c|c|}
\hline Source & df & $\mathrm{NH}_{4}^{+}-\mathrm{N}$ & $\mathrm{NO}_{3}{ }^{-}-\mathrm{N}$ & $\mathrm{P}$ & $\mathrm{K}$ & $\mathrm{Ca}$ & $\mathrm{Mg}$ \\
\hline Rep & 3 & $304^{* * * *}$ & $2796^{* * * *}$ & $32.2^{\mathrm{NS}}$ & $6588^{* * * *}$ & $3357^{* * * *}$ & $3388^{* * * *}$ \\
\hline Rate (R) & 3 & $1145^{* *}$ & $9690^{* *}$ & $1641^{* * *}$ & $16,572^{*}$ & $567^{\mathrm{Ns}}$ & $331^{\mathrm{Ns}}$ \\
\hline Error A & 9 & 162 & 1493 & 119 & 3297 & 1588 & 1391 \\
\hline Sample Size (SS) & 1 & $80.6^{*}$ & $536^{\mathrm{NS}}$ & $64.4^{*}$ & $1757^{* * *}$ & $27.1^{\mathrm{Ns}}$ & $282^{\mathrm{Ns}}$ \\
\hline Method (M) & 1 & $10,871^{* * *}$ & $11,724^{* * * *}$ & $299^{* * * *}$ & $32,361^{\text {**** }}$ & $70,864^{* * *}$ & $45,530^{* * *}$ \\
\hline $\mathrm{SS} \times \mathrm{R}$ & 3 & $4.1^{\mathrm{Ns}}$ & $32.3^{\mathrm{Ns}}$ & $6.9^{\mathrm{Ns}}$ & $36.9^{\mathrm{Ns}}$ & $177^{\mathrm{Ns}}$ & $79^{\mathrm{Ns}}$ \\
\hline $\mathrm{R} \times \mathrm{M}$ & 3 & $56.1^{*}$ & $243^{\mathrm{Ns}}$ & $21.2^{\mathrm{NS}}$ & $716^{\mathrm{Ns}}$ & $501^{\mathrm{NS}}$ & $240^{\mathrm{Ns}}$ \\
\hline $\mathrm{SS} \times \mathrm{M}$ & 1 & $0.6^{\mathrm{NS}}$ & $2.5^{\mathrm{Ns}}$ & $6.8^{\mathrm{Ns}}$ & $86.1^{\mathrm{Ns}}$ & $86^{\mathrm{NS}}$ & $0.1^{\mathrm{NS}}$ \\
\hline $\mathrm{SS} \times \mathrm{R} \times \mathrm{M}$ & 3 & $10.4^{\mathrm{Ns}}$ & $71.8^{\mathrm{NS}}$ & $15.2^{\mathrm{Ns}}$ & $73.2^{\mathrm{Ns}}$ & $150^{\mathrm{NS}}$ & $61.9^{\mathrm{Ns}}$ \\
\hline Error B & 60 & 15.6 & 135 & 15.7 & 364 & 192 & 182 \\
\hline Total MS & & 12,649 & 26,724 & 2221 & 61,851 & 77,509 & 51,485 \\
\hline
\end{tabular}

Ns, *,**,*** Nonsignificant or significant at $P \leq 0.05,0.01$, or 0.001 , respectively.

Table 5. Mean squares from analysis of variance for comparison of extraction methods with two substrates and four fertilizer rates (Expt. 2).

\begin{tabular}{lrcc}
\hline Source & df & $\mathrm{pH}$ & $\mathrm{EC}$ \\
\hline Rep & 4 & $0.11^{* * *}$ & $0.06^{* * *}$ \\
Substrate (S) & 1 & $39.22^{* * *}$ & $0.01^{\mathrm{Ns}}$ \\
Rate (R) & 3 & $1.91^{* * *}$ & $3.18^{* * *}$ \\
$\mathrm{~S} \times \mathrm{R}$ & 3 & $0.10^{*}$ & $0.02^{\mathrm{Ns}}$ \\
Error A & 28 & $0.03^{* * *}$ & 0.01 \\
Method (M) & 2 & $0.73^{* * *}$ & $3.96^{* * *}$ \\
$\mathrm{M} \times \mathrm{S}$ & 2 & $0.07^{* *}$ & $0.01^{\mathrm{Ns}}$ \\
$\mathrm{M} \times \mathrm{R}$ & 6 & $0.01^{\mathrm{Ns}}$ & $0.30^{* * *}$ \\
$\mathrm{M} \times \mathrm{S} \times \mathrm{R}$ & 6 & $0.03^{* * *}$ & $0.03^{* * *}$ \\
Error B & 64 & 0.01 & 0.01 \\
Total & \multicolumn{4}{|c}{42.22} & 7.58 \\
\hline Ns, ${ }^{*},{ }^{* *},{ }^{* * *}$ Nonsignificant & or significant at $P \leq 0.05$,
\end{tabular}

0.01 , or 0.001 , respectively.

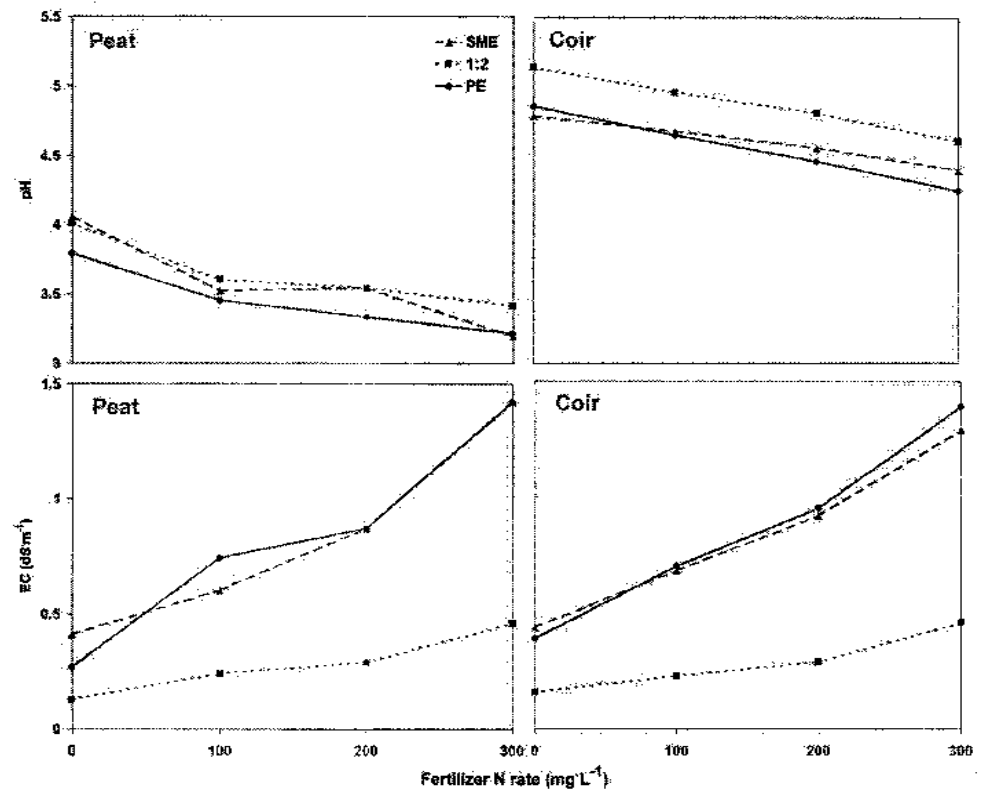

Fig. 1. Effects of $\mathrm{N}$ rate, substrate, and extraction method on substrate pH and EC (Expt. 2).

Table 6. Relationship between the press extraction method (PE) vs. saturated media extraction (SME) for $\mathrm{pH}$ and electrical conductivity (EC) values of peat- and coir-based substrates (Expt. 2).

\begin{tabular}{lclc}
\hline & Substrate & \multicolumn{1}{c}{ Equation $^{2}$} & $R^{2}$ \\
\hline $\mathrm{pH}$ & Peat & $\mathrm{y}=-0.39 \mathrm{x}^{2}+3.5 \mathrm{x}-4.02$ & 0.90 \\
& Coir & $\mathrm{y}=-1.58 \mathrm{x}-2.71$ & 0.92 \\
$\mathrm{EC}$ & Peat & $\mathrm{y}=0.87 \mathrm{x}+0.13$ & 0.87 \\
& Coir & $\mathrm{y}=1.14 \mathrm{x}-0.09$ & 0.96
\end{tabular}

${ }^{\mathrm{z}} \mathrm{For} \mathrm{pH}, \mathrm{y}=\mathrm{pH}$ for the PE method and $\mathrm{x}=\mathrm{pH}$ for the SME method; for

$\mathrm{EC}, \mathrm{y}=\mathrm{EC}$ for the PE method and $\mathrm{x}=\mathrm{EC}$ for the SME method.

had a significant effect (Table 7). Across all $\mathrm{N}$ levels, the average level of $\mathrm{NH}_{4}{ }^{+}-\mathrm{N}$ was 5.6 times greater in peat than in coir (Table 8). The peat solution was also higher in $\mathrm{NO}_{3}^{-}-\mathrm{N}, \mathrm{Ca}$, and $\mathrm{Mg}$, but the coir extract contained higher levels of $\mathrm{K}$ and $\mathrm{Na}$. Levels of $\mathrm{K}$ and $\mathrm{Na}$ in Coir vary with source (Konduru et al., 1999) and are often relatively high when compared with those in sphagnum peat (Evans et al., 1996). Fertilizer rate had the greatest influence on extract concentrations of $\mathrm{NO}_{3}^{-}-\mathrm{N}, \mathrm{P}, \mathrm{Ca}$, and $\mathrm{Mg}$. The slope of PE across fertilizer rates for these elements differed from the slope of SME; however, significant interactions between fertherefore nutrient means for individual extraction methods are not presented here. Substrate creasing the increments between fertilizer rates izer supplying additional $\mathrm{Ca}$ and $\mathrm{Mg}$ resulted (Fig. ignificant extraction method main effect for the other two methods. The EC values for PE in levels of saturation between Expt. 1 and Expt. 2. Apparently less water was needed to There is no specific protocol other than the degree of saturation for the SME, although the quantity of water used can influence soluble Nutrients. Extraction method significan affected all macronutrients except $\mathrm{NH}_{4}{ }^{+} \mathrm{N}$ and $\mathrm{K}$ (Table 7). However, method accounted for $2 \%$ or less of the variation for any nutrient, 
Table 7. Mean squares from analysis of variance for macronutrient content of peat- vs. coir-based substrate (Expt. 2).

\begin{tabular}{|c|c|c|c|c|c|c|c|c|}
\hline Source & df & $\mathrm{NH}_{4}{ }^{+}-\mathrm{N}$ & $\mathrm{NO}_{3}^{-}-\mathrm{N}$ & $\mathrm{P}$ & $\mathrm{K}$ & $\mathrm{Ca}$ & $\mathrm{Mg}$ & $\mathrm{Na}$ \\
\hline Rep & 4 & 5.67 & 78.00 & $15.84^{* * *}$ & 239.30 & $19.36^{* *}$ & $10.33^{* * *}$ & $26.42^{* *}$ \\
\hline Substrate (S) & 1 & $5,015.40^{* * * *}$ & $714.27^{* *}$ & $101.48^{* * * *}$ & $22,470.90^{* * *}$ & $1,087.84^{* * *}$ & $705.47^{* * *}$ & $14,243.00^{* * * *}$ \\
\hline Rate (R) & 3 & $551.07^{* * * *}$ & $42,018.71^{\text {**** }}$ & $1608.08^{* * * *}$ & $5,849.30^{* * *}$ & $1,753.51^{* * *}$ & $1,659.11^{* * * *}$ & $8,420.40^{* * * *}$ \\
\hline $\mathrm{S} \times \mathrm{R}$ & 3 & $105.65^{\text {**** }}$ & 143.63 & $10.18^{* *}$ & $2,560.70^{* * * *}$ & $276.78^{* * * *}$ & $103.34^{* * * *}$ & $188.82^{* * * *}$ \\
\hline Error A & 28 & 3.18 & 64.43 & 2.06 & 92.65 & 4.56 & 3.34 & 6.07 \\
\hline Method (M) & 1 & 20.62 & $1,100.02^{* *}$ & $16.15^{* *}$ & 344.15 & $139.42^{* * *}$ & $41.83^{* * *}$ & $504.43^{* * * *}$ \\
\hline $\mathrm{M} \times \mathrm{S}$ & 1 & $34.37^{*}$ & 241.84 & 1.89 & $3,012.15^{* * *}$ & $27.06^{*}$ & 9.01 & $93.87^{* *}$ \\
\hline $\mathrm{M} \times \mathrm{R}$ & 3 & 3.09 & $412.3^{* * *}$ & $20.31^{* * * *}$ & $447.98^{* *}$ & $126.56^{* * * *}$ & $11.42^{*}$ & 15.21 \\
\hline $\mathrm{M} \times \mathrm{S} \times \mathrm{R}$ & 3 & 2.41 & 15.97 & 1.01 & 293.08 & 5.72 & 6.06 & 1.27 \\
\hline Error B & 31 & 5.13 & 87.30 & 1.79 & 89.24 & 173.72 & 2.55 & 10.04 \\
\hline Total & & $5,746.59$ & $44,876.47$ & $1,778.80$ & $35,399.45$ & $3,608.59$ & $2,552.46$ & $23,509.53$ \\
\hline
\end{tabular}

*,**,***Significant at $P \leq 0.05,0.01$, or 0.001 , respectively.

Table 8. Effects of substrate and rate of $\mathrm{N}$ application on nutrient content $\left(\mathrm{mg} \cdot \mathrm{L}^{-1}\right)$ of substrate (Expt. 2) [peat (P), coir (C)].

\begin{tabular}{|c|c|c|c|c|c|c|c|c|c|c|c|c|c|c|}
\hline \multirow{2}{*}{$\begin{array}{l}\mathrm{N} \text { rate } \\
\left(\mathrm{mg} \cdot \mathrm{L}^{-1} \mathrm{~N}\right)\end{array}$} & \multicolumn{2}{|c|}{$\mathrm{NH}_{4}{ }^{+}-\mathrm{N}$} & \multicolumn{2}{|c|}{$\mathrm{NO}_{3}{ }^{-} \mathrm{N}$} & \multicolumn{2}{|c|}{$\mathrm{P}$} & \multicolumn{2}{|c|}{$\mathrm{K}$} & \multicolumn{2}{|c|}{$\mathrm{Ca}$} & \multicolumn{2}{|c|}{$\mathrm{Mg}$} & \multicolumn{2}{|c|}{$\mathrm{Na}$} \\
\hline & $\mathrm{P}$ & $\bar{C}$ & $\bar{P}$ & $\mathrm{C}$ & $\mathrm{P}$ & $\bar{C}$ & $\mathrm{P}$ & $\mathrm{C}$ & $\mathrm{P}$ & $\mathrm{C}$ & $\mathrm{P}$ & $\bar{C}$ & $\mathrm{P}$ & $\mathrm{C}$ \\
\hline 0 & $11^{*}$ & 2 & $5^{*}$ & 4 & $5^{*}$ & 4 & $9^{*}$ & 88 & 6 & 6 & 4 & 4 & $19^{*}$ & $\overline{40}$ \\
\hline 100 & $18^{*}$ & 3 & $29^{*}$ & 27 & $11^{*}$ & 9 & $33^{*}$ & 136 & 10 & 7 & $10^{*}$ & 5 & $24^{*}$ & 50 \\
\hline 200 & $24^{*}$ & 4 & $71^{*}$ & 58 & $18^{*}$ & 15 & $63^{*}$ & 174 & $18^{*}$ & 9 & $18^{*}$ & 9 & $27 *$ & 54 \\
\hline 300 & $29^{*}$ & 9 & $115^{*}$ & 107 & $27^{*}$ & 24 & $111^{*}$ & 245 & $36^{*}$ & 18 & $30^{*}$ & 19 & $28^{*}$ & 64 \\
\hline & $\mathrm{L}^{* * * *}$ & $\mathrm{Q}^{* * * *}$ & $\mathrm{Q}^{*}$ & $\mathrm{Q}^{* * * *}$ & $\mathrm{Q}^{*}$ & $\mathrm{Q}^{* *}$ & $\mathrm{Q}^{* *}$ & $\mathrm{Q}^{*}$ & $\mathrm{Q}^{* * *}$ & $\mathrm{Q}^{* * *}$ & $\mathrm{Q}^{* * * *}$ & $\mathrm{Q}^{* * * *}$ & $\mathrm{Q}^{*}$ & $\mathrm{~L}^{*}$ \\
\hline
\end{tabular}

*Significantly different from corresponding value for coir, $P \leq 0.05$.

${ }^{*, * * * * * *}$ Significant at $P \leq 0.05,0.01$, or 0.001 , respectively; $\mathrm{L}=$ linear, $\mathrm{Q}=$ quadratic.

tilizer rate and extraction method main effects were small $(<1 \%$ of total MS) (Table 7$)$.

Strong correlations between the PE and SME in Expt. 2 suggest that existing SME standards could be used to interpret nutrient analysis results for a PEextract. The PE method is a practical and logical alternative to current testing methods; however, standards for its use must be generated. The PE is a low-dilution extraction method, similar to the pour-through (PT) method. Results from this study parallel those found by researchers comparing PT with SME and other substrate: water slurries. Wright et al. (1990) found that the PT extract higher in $\mathrm{EC}$ and tested nutrients, but the $\mathrm{pH}$ was quite similar to that for SME in potted poinsettia (Euphorbia pulcherrima Willd. Ex Klotzsch.) production. Yeager et al. (1983) noted similar results when testing a pine bark substrate. Though the PT may not be feasible for plug testing, research results are analogous to the PE. Future work can yield greenhouse $\mathrm{pH}$ and EC standards adaptable to both methods. However, current standards for seedlings exist only for the SME and 1:2 methods. Understanding the relationships among these methods is an important step in the development and implementation of the PE for plug production.

\section{Literature Cited}

Compton, A.J. and P.V. Nelson. 1997. Timing is crucial for plug seedling substrate testing. HortTechnology 7:63-68.

Evans, M.R., S. Konduru, and R.H. Stamps. 1996 Source variation in physical and chemical properties of coconut coir dust. HortScience 32:965-967.

Fonteno, W.C. 1996. Growing media: Types and physi$\mathrm{cal} /$ chemical properties, p. 93-122. In: D.W. Reed (ed.). Water, media, and nutrition for greenhouse crops. Ball, Batavia, Ill.

Fonteno, W.C., D.A. Bailey, and P.V. Nelson. 1995 Squeeze your plugs for simple, accurate nutrient monitoring. GrowerTalks 59(9):22, 24, 26-27.

Handreck, K.A. 1993. Properties of coir dust, and its use in the formulation of soilless potting media. Commun. Soil Sci. Plant Anal. 24:349-363.

Handreck, K.A. 1994. Pour-through extracts of potting media: Anomalous results for $\mathrm{pH}$. Commun. Soil Sci. Plant Anal. 25:2081-2088.

Konduru, S., M.R. Evans, and R.H. Stamps. 1999. Coconut husk and processing effects on chemical and physical properties of coconut coir dust. HortScience 34:88-90.

Lang, H.J. 1996. Growing media testing and interpretation, p. 123-139. In: D.W. Reed (ed.). Water, media, and nutrition for greenhouse crops. Ball, Batavia, Ill.

Meerow, A.W. 1995. Growth of two tropical foliage plants using coir dust as a container medium amendment. HortTechnology 5:237-239.

Nelson, P.V. 1998. Greenhouse operation and management. 5th ed. Simon \& Schuster, Upper Saddle River, N.J.
Poole, R.T. and A.R. Chase. 1987. Response of foliar plants to fertilizer application rates and associated leachate conductivity. HortScience 22:317-318.

Scoggins, H.L., P.V. Nelson, and D.A. Bailey. 2000. Development of the press extraction method for plug substrate analysis: Effects of variable extraction force on $\mathrm{pH}, \mathrm{EC}$, and nutrient analysis. HortTechnology 10:367-369.

Sonneveld, C. 1990. Estimating quantities of watersoluble nutrients in soils using a specific $1: 2$ by volume extract. Commun. Soil Sci. Plant Anal. 21:1257-1265.

Sonneveld, C., J. van den Ende, and P.A. van Dijk. 1974. Analysis of growing media by means of a 1:1 1/2 volume extract. Commun. Soil Sci. Plant Anal. 5:183-202.

Stamps, R.H. and M.R. Evans. 1997. Growth of Dieffenbachia maculata 'Camille' in growing media containing sphagnum peat or coconut coir dust. HortScience 32:844-847.

Warncke, D.D. 1986. Analyzing growth media by saturation extraction procedure. HortScience 21:223-225.

Warncke, D.D. 1990. Testing artificial growth media and interpreting the results, p. 337-357. In: Soil testing and plant analysis, 3rd ed. Soil Sci. Soc. Amer., Madison, Wis.

Wright, R.D., K.L. Grueber, and C. Leda. 1990. Medium nutrient extraction with the pour-through and saturated medium extraction procedures for poinsettia. HortScience 25:658-660.

Yeager, T.H., R.D. Wright, and S.J. Donohue. 1983. Comparison of pour-through and saturated pine bark extract N, P, K, and pH levels. J. Amer. Soc. Hort. Sci. 108:112-114. 